\title{
A SETI MINT TUDOMÁNY? MÚLT, JELEN, JÖVŐ
}

\section{SETI AS SCIENCE? PAST, PRESENT, AND FUTURE}

\author{
Galántai Zoltán \\ $\mathrm{PhD}$, egyetemi docens \\ Eötvös Loránd Tudományegyetem Gazdálkodástudományi Intézet Összehasonlító Gazdaságtan Tanszék, \\ Neumann János Egyetem Gazdaságtudományi Kar Közgazdaságtan és Jog Tanszék
}

\begin{abstract}
ÖSSZEFOGLALÁS
A hipotetikus földönkívüli civilizációk kutatásának modern irányzata, a SETI (Search for Exraterrestrial Intelligence) 1960 körül jelent meg, viszont még ma sem élvezi ugyanazt a tudományos elismertséget, mint például a vele nagyjából egy időben kialakuló, ám hozzá hasonlóan kézzel fogható eredményeket mindeddig felmutatni képtelen asztrobiológia. A cikk egyfelől azt tekinti át tudománytörténeti szempontból, hogy a távcső megjelenése óta milyen megfontolások befolyásolták a témával foglalkozó kutatók gondolkodását, és az a 17. század elején megjelenő meggyőződés, mely szerint a többi bolygó hasonlít a Földhöz, miként tette általánosan elfogadhatóvá azt a meggyőződést, hogy rajtunk kívül is léteznek értelmes lények. Másfelől megvizsgáljuk, hogy a modern SETI esetében általában miért a mesterséges jelek utáni kutatás dominált, és ezzel párhuzamosan miként vált lehetővé, hogy tudományosan meg nem alapozott spekulációk is megjelenjenek. Végezetül kitérünk rá, hogy milyen hatásai lehetnek a SETI-re, ha a jelenlegi tendenciákkal összhangban a kutatásban az eddiginél nagyobb szerepet kapnak a társadalomtudományok.
\end{abstract}

\section{ABSTRACT}

The modern approach of the search for extraterrestrial civilizations named SETI (Search for Extraterrestrial Intelligence) has appeared around 1960, but still, it has not been as accepted scientifically as the astrobiology that appeared parallel with it, and, similarly, unable to present an acceptable result. On the one hand, we sum up the history of science's approach to the developments of this field since the early $17^{\text {th }}$ century, when, after the spread of the telescope as a scientific tool, it became wildly accepted that the other planets of the Solar System are similar to the Earth and thus they are populated with intelligent beings. On the other hand, we shall examine why the search for the artificial sings dominated the modern SETI, and in parallel with it how it became possible to scientifically bad theories to influence this field. Finally, it is important to examine-in accordance with today's tendencies-the possible impact of the involvement of social sciences into the SETI researches.

Kulcsszavak: SETI, idegen civilizációk kutatása, tudománytörténet, természettudomány, társadalomtudomány, kritika

Keywords: SETI, research of alien civilizations, history of science, natural science, social science, criticism 


\section{BEVEZETÉS}

Miközben a SETI-vel (Search for Exraterrestrial Intelligence) foglalkozó kutatók szeretik azt hangoztatni, hogy ha tudnánk, hogy léteznek-e rajtunk kívül más értelmes lények a világmindenségben, az mindent megváltoztatna, aközben a téma általános megítélése teljesen más. Mindmáig ki van téve a „kuncogási faktornak”, vagyis annak, hogy mint tudománytalan tevékenységet figurázzák ki, még akkor is, ha a kívülállók éppen nem keverik össze az UFO-lógiával. Vagyis a SETI-nek mindeddig nem sikerült ugyanolyan tudományos elismertséget kivívnia, mint az asztrobiológiának, amely egyébként hozzá hasonlóan abból indul ki, hogy az élet általános jelenség az univerzumban, és amely mindeddig szintén nem tudott eredményeket felmutatni.

Az alábbiakban elsősorban tudománytörténeti megközelítésből azt elemezzük, hogy miként változtak a hipotetikus földönkívüliekkel kapcsolatos meggyőződések a távcső megjelenése óta; ezeknek milyen összetevői voltak, és miként változhat a SETI értelmezése a jövőben.

\section{A SETI ELŐTÖRTÉNETE: A BOLYGÓK ÉS A TEOLÓGUSOK}

Már az ó-, illetve a középkorban is felmerült a kérdés, hogy vannak-e más, „lakott világok". Epikurosz és más atomisták úgy gondolták, hogy a végtelen számú atom létezéséből szükségképpen a végtelen számú világ létezése is következik, de nem az ő meggyőződésük vált meghatározóvá, és a távcső megjelenése előtti időszakra az a sajátos helyzet állt elő, hogy miközben az arisztotelészi fizika lényegében tagadta a „más világok” létezésének a lehetőségét, a teológusok amellett érveltek, hogy Isten legalábbis teremthetne ilyeneket, ha akarna. Eközben a 'világok' alatt leginkább Föld-szerü égitesteket értettek (Crowe, 1982).

És a 17. századtól, a távcső megjelenésétől is leginkább egyfajta „bolygóközpontú" megközelítés vált meghatározóvá. Eszerint, mivel a heliocentrikus felfogással összehangban a Föld csupán egyike a Nap körül keringő bolygóknak, ezért „ugyanolyan”, mint azok. Ami nyilván fordítva is igaz: azok is ugyanolyanok, mint a Föld, és innentől kezdve csupán az volt kérdés, hogy mit is értünk az ,ugyanolyan” alatt: azt-e, hogy hegyek és tengerek borítják az adott égitestet (miként az akkori elképzelések szerint a Holdat), vagy azt, hogy mivel hasonlít a Földhöz, és mivel a Föld lakott, ezért a többi bolygó (általánosítva: a Naprendszer többi égiteste) is ugyanilyen. Emellett persze a teológiai érvelések is szerepet játszottak egészen a 19. század második feléig akár pro, akár kontra: nemcsak amellett hangzottak el érvek, hogy más értelmes lények léte Isten nagyságát bizonyítja, de - olykor - amellett is, hogy mivel a Teremtés célja az ember, ezért szükségképpen egyedül vagyunk (Guthke, 1990). 
Mindenesetre nem véletlen, hogy Kepler Álom címü posztumusz müvében már holdbéli „városokról” írt a 17. század elején, anélkül hogy különösebb figyelmet szentelt volna annak a megkülönböztetésnek, hogy egy idegen égitest csupán élettel vagy értelmes élettel is benépesített-e (Basalla, 2006). Ugyanis egészen az evolúciós elmélet megjelenéséig mindkettő ,az olyan, mint a Föld” egységcsomag része volt, és csak azt követően vált a kutatás két részre, hogy felmerült a kérdés, az evolúció mennyire törvényszerủen vezet el az értelem megjelenéséhez. Amíg ugyanis az idegen bolygókat is a Teremtő müveinek tekintették, és amíg ennek megfelelően az is természetesnek tünt, hogy másutt is ugyanaz a teremtés ment (vagy legalábbis mehetett volna) végbe, mint nálunk, addig ennek a megkülönböztetésnek nem volt értelme.

\section{A SETI HIÁNYA ÉS A BIZONYITTÉK HIÁNYA}

Az idegen értelem utáni kutatás felfogható úgy, hogy itt a távcső megjelenése óta a tények hiányában mindig is azoknak a hasonlatoknak volt alapvető szerepük, amelyeken keresztül értelmezni próbáltuk a kérdést. Vagyis hosszú ideig annak, hogy egyszerủen a Földhöz hasonló bolygóként írtuk le a hipotetikus idegenek lakhelyét; mára pedig annyit változott a kép, hogy leginkább hasonló körülmények között működő ökoszisztémaként. Ezért is szokás „életzónában” (lakhatósági zónában) keringő bolygókról beszélni, és a jelenlegi exobolygó-keresést a SETI-vel is összekapcsolni.

Logikailag azonban csak a végtelen számú világ létére építő atomista értelmezés tette volna szükségszerủvé annak feltételezését, hogy másutt is van értelmes élet. Eszerint ugyanis, amennyiben minden lehetőség végtelenül sokszor megvalósul, akkor az értelmes életnek is végtelenül sok alkalommal kell megjelennie. De a „hasonló bolygók” esetében ez nem szükségszerü, hacsak a hasonlóságba bele nem értjük az értelmes élet jelenlétét - miközben éppen az a kérdés, hogy tényleg ez-e a helyzet.

A SETI hívei arra szoktak hivatkozni az értelemes idegen élet jeleinek hiányával kapcsolatban, hogy a „bizonyíték hiánya még nem a hiány bizonyítéka” (Almár, 1999), ám ez önmagában, ha más érvek nem támasztják alá, nem védhető. Hiszen ezzel az erővel, hogy a filozófus Bertrand Russel által használt hasonlattal éljünk, akár azt is állíthatnánk, hogy az olümpiai istenek léteznek - elvégre nem látta öket senki. Azaz: csupán abból, hogy nem észleltünk valamit, nem vonható le az a következtetés, hogy akkor nem zárható ki a léte (vagy egyenesen az, hogy minden bizonnyal létezik). Ehhez szükség lenne egy olyan elméletre, amely megalapozza a feltételezést, hogy akár az olümpiai istenek, akár a hipotetikus idegenek léteznek.

Ám éppen ez az, amivel egyelőre nem rendelkezünk. 


\section{A KUTATÁS TECHNOLÓGIÁl}

És ezen a ponton el is jutunk a technológia kérdéséhez, illetve ahhoz, hogy a földönkívüli értelem keresése az alapján is korszakolható, hogy mikor és milyen megfigyelési eszközöket tekintettek elsődlegesnek.

A 17. századig nem igazán voltak ilyenek. A távcső megjelenése után bár akadtak, akik nem foglalkoztak a kérdéssel (például Galilei), a túlnyomó többség Christiaan Huygenstől John Herschelig és Percival Lowellig abból indult ki, hogy ha megvannak a megfelelő müszereink, akkor előbb-utóbb meglesz a válasz is - azzal azonban nem foglalkoztak, hogy miért is kellene azt gondolnunk, hogy a távcső jelenti a megoldást. És azért nem, mert a „többi bolygó is olyan, mint a Föld" modell alapján úgy gondolták, hogy mivel minden bizonnyal „ott vannak" az idegenek, ez immár egyszerü megfigyelési kérdés. Így a 18. századra a földönkívüli értelem kutatása bekerült a csillagászok megfigyelési programjába is, viszont egészen a 20. század elejéig kizárólag a Naprendszeren belül folyt a keresés. Sőt, még az 1920-as években, az első rádióészlelések idején is a Marsról reméltek jelet fogni (Dick, 1999).

Aztán a modern SETI 1950-es évek végi kialakulása hosszú évtizedekre a rádiótávcsövet tette a kutatások alapeszközévé - a kutatások színhelyévé pedig a Tejútrendszert (bár Nyikolaj Kardasov és más szovjet csillagászok felvetették, hogy esetleg egy másik galaxis szupercivilizációinak tevékenységét is észlelni lehetne). És a 21. század elején azzal együtt, hogy az exobolygó-keresés került előtérbe, új távcsöves, illetve számítógépen alapuló megfigyelési módszerek is megjelentek.

Az persze vitathatatlan, hogy az alkalmazott módszer/technológiai megoldás fontos lehet, és a tudománytörténész Peter Galison a kuhni tudományos forradalmak analógiájára egyenesen a technológiavezérelt forradalmak fogalmát vezette be, melyekből Freeman Dyson amerikai fizikus mintegy másfél tucatot különböztet meg „Galilei távcsövétől” a mikroszkópig és a röntgentechnológiáig. Viszont egy technológiavezérelt forradalom sem teljesen független a tudományos háttértől. Hiába rendelkezünk például távcsővel, emellett szükségünk van egy olyan bolygóértelmezésre is, amely szerint az idegen égitestek lakottak lehetnek, hogy úgy gondolhassuk: az optikai észlelés segítségével választ kaphatunk a kérdésekre.

Tehát a tudományos forradalom-technológiavezérelt forradalom szembeállítása helyett érdemesebb a két terület kölcsönös egymásra hatásán alapuló, koevolúciós fejlődéséről beszélni: a relativitáselméletek létrejöttében például a kortárs fizikai elméletek mellett jelentős szerepet játszott az is, hogy Albert Einstein a berni szabadalmi hivatalban egy, a vasúti közlekedés számára alapvető fontosságú kérdéssel: az elektromos órák szinkronizálásának problémájával találkozott (Agar, 2012). 


\section{A SETI, COCCONIÉS MORRISON}

Azaz ugyanúgy hiba lenne kizárólag a tudományos elméletekre fókuszálni, mint ahogy hiba lenne kizárólag a technológiára is. Viszont amikor két fizikus: Giuseppe Cocconi és Philip Morrison 1959-ben cikket jelentetett meg a Nature-ben az idegen civilizációk kutatásáról, akkor ők nem tértek ki az elméleti kérdésekre. Sőt.

Ma innentől szokás a modern SETI kezdeteit számítani, és bár elvileg arra keresik a választ, hogy lehetséges-e felvenni a kapcsolatot más civilizációkkal, sem a biológia (élet és értelmes élet), sem a társadalomtudomány ezzel kapcsolatos aspektusaival (civilizációk) nem foglalkoznak - noha ahhoz, hogy egyáltalán felvethessük a kérdést, hogy vannak-e rajtunk kívül értelmes lények a világmindenségben, ezeket sem lehetne figyelmen kívül hagyni. Azaz: bár a SETI abból a szempontból komplex tudomány, hogy nem szükíthető le egyetlen, hagyományos tudományterületre (mondjuk a fizikára vagy éppen az antropológiára), és ennek megfelelően nem is lehet egyetlen terület szakértőinek illetékességéhez rendelni, itt lényegében mégis ez történt - és ez a csillagászat, illetve leginkább a rádiócsillagászat volt.

Cocconi és Morrison ugyanis abból indultak ki, hogy nincs megbízható elméletünk ,(1) a bolygókeletkezés valószínüségére; (2) az élet eredetére; (3) azon társadalmak evolúciójára, melyek fejlett tudománnyal rendelkeznek". Nota bene: a 2. és 3. ponttal kapcsolatban - noha ezek alapvetőek a SETI számára - ma sem tudunk többet, és az, hogy az egyik területen (bolygókeletkezés) elörelépést tettünk azóta, szükségesnek szükséges ugyan, de nem elégséges. Nem feltétlenül következik ugyanis belöle, hogy a másik két területen is áttörést fogunk elérni.

A cikk viszont egyáltalán nem tárgyalta ezt a problémát. Ehelyett az a kijelentés következett, hogy ,az elméletek hiányában a saját környezetünk [példája] azt sugallja, hogy a csillagoknak... milliárd éves élettartamuk alatt lehetnek bolygóik, és a bolygók ezen kicsiny halmazából kettő (a Föld meg nagy valószínüséggel a Mars) életet hordoz, és az egyik bolygón olyan társadalom létezik, amely jelenleg figyelemre méltó tudományos teljesítményre képes".

Ha azt figyelmen kívül hagyjuk is, hogy a Marssal kapcsolatban tévedtek, az, hogy a más naprendszerek létével kapcsolatban igazuk lett, nem több szerencsés találgatásnál, ugyanis megfelelő információk nélkül (miként 1959-ben még ez volt a helyzet), egyetlen példából nem lehet következtetéseket levonni. Vagyis Cocconi és Morrison itt nem következtettek, hanem egyszerüen egy olyan állítást fogalmaztak meg, amely lehetővé tette, hogy foglalkozzanak az őket érdeklő probléma: az idegen értelem által küldött jelek detektálásával.

Pedig a saját helyzetünkből általánosítani már csak azért is problémás, mert abból a szempontból mindenképpen kitüntetett helyzetben vagyunk, hogy szükségképpen az életre és az értelmes életre alkalmas környezetet kell megfigyelnünk 
magunk körül - máskülönben nem tehetnénk megfigyeléseket. Viszont ebböl nem következik (csupán nem zárható ki), hogy másutt is ez a helyzet. Egyébként hasonló a gond az ún. Drake-formulával is, amely a SETI talán legismertebb képlete, és amely egyszerüen felsorolja, hogy milyen feltételeknek kellene teljesülniük egy technikai civilizáció megjelenéséhez kezdve a bolygókeletkezésen és folytatva az életzónában keringő bolygókon; az élet létrejöttén; az értelmes élet megjelenésén meg azon, hogy az idegen társadalmaknak elég hosszú ideig fenn kell maradniuk ahhoz, hogy kapcsolatba léphessünk velük. Csak éppen mivel jelenleg, miként már említettük, a bolygókeletkezés kivételével egyik tényezőhöz sem tudunk valószínüséget rendelni, ezért lehetetlen megmondani, hogy mi lesz a végeredmény, és hány ilyen létezik. És akkor azt még nem is említettük, hogy a kizárólag hozzánk nagyon hasonló technikai civilizációk keresése esetleg azt eredményezi, hogy egy kevésbé hasonlót, ami mondjuk nem egy, az ún. életzónában keringő bolygón alakult ki, nem fogunk észrevenni.

\section{IDEGEN CIVILIZÁCIÓK ÉS IDEGEN TÁRSADALMAK}

Cocconi és Morrison cikke azzal folytatódik, hogy az idegen „társadalmak élettartama nem ismert, ám indokolatlan lenne tagadni, hogy ezek között lehetnek olyanok, melyek az emberi történelemhez képest nagyon hosszú ideig fennmaradnak". Azaz itt már nem csupán kiterjesztik a földi megfigyelések érvényességét, és abból, hogy itt léteznek civilizációk, nem csupán arra következtetnek, hogy akkor másutt is létezhetnek hasonlóak. Hanem arra is, hogy más civilizációk jóval hosszabb életủek lehetnek a mieinknél - noha ilyenekre még csak példát sem ismerünk. Abból, hogy van, aki több mint száz évig él, nem feltétlenül következik, hogy van, aki évezredekig.

Ez a hasonlat valószínüleg érzékelteti a Cocconi és Morrison által alkalmazott megközelítéssel kapcsolatos gondokat, még akkor is, ha kérdéses, hogy tényleg párhuzamba állíthatjuk-e egy ember meg egy civilizáció ,élettartamát”, noha a SETI-vel foglalkozó szakirodalomban nagyon is szokás „fiatalabb” és „idősebb” civilizációkról beszélni. Illetve szokás azzal a feltételezéssel élni, hogy ha egy civilizáció „idősebb”, akkor „fejlettebb” is. A téma elismert kutatója, Jill Tarter például egyenesen azzal érvel, hogy ,jobbak és szelídebbek vagyunk, mint a múltban", és ebből arra következtet, hogy a jövőben nyilván még jobbak és még szelídebbek leszünk. És amennyiben ez így van, akkor szerinte az idegen civilizációk esetében is ugyanez a helyzet.

Viszont a filozófus Nicholas Rescher arra hívja fel a figyelmet, hogy csak hasonló dolgokat lehet összehasonlítani. Mondhatjuk például, hogy egy kezdő zongorista rosszabbul játszik, mint egy zongoramüvész, a kínai szakácsmüvészet viszont nem „fejlettebb” vagy „fejletlenebb” a római üvegmüvességnél, hanem 
más (Lamb, 2004). Ahhoz, hogy két civilizációt összehasonlíthassunk, azt kellene feltételeznünk, hogy hasonlóak. És ez még akkor sem szükségszerü, ha olyan idegeneket keresünk, akik rádiójeleket használnak - hacsak nem azt akarjuk állítani, hogy minden civilizáció szükségképpen egyformán fejlődik, és egyetlen úton juthat csak el például a rádiótávcsövek építéséig.

Az antropológus Lewis Henry Morgan a szociáldarwinizmusból kiindulva az 1800-as évek végére dolgozott ki egy olyan modellt, amelyben minden társadalom ugyanazt az utat futva be a „vadság” állapotától a „civilizációig” jut el. Viszont a szintén antropológus Franz Boas már az 1920-as években kimutatta, hogy a különböző társadalmak különböző utakat követhetnek, és az unilineáris leírás nem felel meg a valóságnak.

Ráadásul a hagyományos SETI-kutatás Cocconitól és Morrisontól Tarterig hajlamos úgy beszélni különböző kulcsfogalmakról, hogy adottnak veszik a jelentésüket, kezdve a 'civilizáció'-n befejezve a 'jóindulatú'-n, noha egyáltalán nem mindegy, és megfelelő definíció híján nem is egyértelmü, hogy mit értünk ezek alatt. Tehát innentől kezdve legalábbis kérdéses, hogy miként lehetne érdemi megállapításokat tenni velük kapcsolatban.

De, hogy még egyszer visszatérjünk magához a cikkhez, ez azzal a SETI-vel foglalkozók körében majdhogynem mantrává vált mondattal fejeződik be, hogy „a siker valószínüségét nehéz megbecsülni; de ha soha nem folytatunk keresést, akkor nulla az esélyünk" (Cocconi-Morrison, 1959).

Ami egyfelől persze így van; másfelöl azonban kimondottan félrevezető abban az értelemben, hogy a Cocconi és Morrison által képviselt és a következő évtizedeket meghatározó felfogásnak nem az lett volna az egyetlen alternatívája, hogy akkor ne is foglalkozzunk a hipotetikus idegen civilizációkkal. Felmerülhetett volna például az is, hogy a technikai keresésre való koncentrálás helyett legyen elsődleges (vagy legalább hasonlóan fontos) a kulcsfogalmak tisztázása és az illetékes tudományterületek bevonása, ahelyett hogy bizonyos értelemben egyszerüen továbbvittük volna azt a 17. századi felfogást, mely szerint az idegen bolygók „olyanok, mint a Föld” a rajtuk élőkkel együtt.

\section{KIS LÉPÉSBŐL NAGY UGRÁS?}

Természetesen hiba lenne azt állítani, hogy Cocconit és Morrisont meg az őket követő amerikai SETI-kutatókat ne befolyásolták volna a technológiaiakon kívül egyéb megfontolások is. És arról sincs szó, hogy ez a cikk vitte volna félre a SETI-kutatást - inkább csak összhangban volt az akkoriban a csillagászok jelentös része által elfogadott felfogással.

Amit nagymértékben befolyásolt, elöször is az, hogy az I. világháború idején kidolgozott Jeans-féle modell, amely szerint a bolygókeletkezés rendkívül ritka 
jelenség, az 1950-es évekre elveszítette a támogatottságát. Ez azon a feltételezésen alapult, hogy a bolygók akkor jönnek létre, ha két nagy tömegü csillag halad el egymás mellett, viszont - egyebek között - nem tudta megmagyarázni a bolygók perdületét sem.

Ezért válhatott általánossá az a meggyőződés a II. világháború utánra, hogy ha nem szükségszerü, hogy csak ritkán jöhetnek létre, akkor minden bizonnyal számos bolygórendszer létezik - bár ez valójában nem következik ebből. Viszont legalábbis nem mondott ellen annak a meggyőződésnek, hogy számos élettel, illetve értelmes élettel benépesített égitest létezhet.

A SETI-vel kapcsolatos felfogást befolyásoló tényezők között megemlítendő a Miller-Urey-kísérlet is 1952-ből, amellyel kapcsolatban a „kis lépésből nagy ugrás" logikai hibát elkövetve azt volt szokás feltételezni, hogy amennyiben az élet egyes építőköveit viszonylag egyszerüen elő lehet állítani laboratóriumi körülmények között, akkor magával az élettel is ez a helyzet. Értsd: mivel egyszerüen létrejöhet, ezért gyakori jelenség.

Illetve megemlítendő a behaviourizmus is, mely - kissé leegyszerüsítve bár, de - úgy tartotta, hogy kizárólag a laboratóriumi körülmények között vizsgálható kérdéseknek van létjogosultságuk, ám azt kérdezni, hogy mit „gondol” egy élölény, illetve, hogy értelmes-e, nincs. Ugyanis erröl nem tudunk megbizonyosodni - csak arról, hogy miként viselkedik. Ekkor viszont az is értelmetlen kérdésnek tünik, hogy milyen és a miénktől mennyire eltérő intelligenciák lehetségesek (Sheridan, 2011).

\section{EGY MÁSIK MEGKÖZELÍTÉS}

Ehhez képest a földönkívüliekkel kapcsolatos kutatásokban részt vevő szovjet kutatók kiindulási pontja viszont az volt, hogy az anyag fejlődése a dialektikus materializmus értelmében szükségképpen elvezet az értelmes élet kialakulásához. Ez ma már nem számít védhető álláspontnak, viszont annyiban mégis említésre méltó, hogy ezért beszéltek a szovjetek SETI helyett inkább CETI-ről (Communication with Extraterrestrial Intelligence). És mivel biztosra vették, hogy léteznek idegen civilizációk, ezért nem annyira magát a keresést tartották fontosnak, hanem az ezzel kapcsolatban felmerülő elvi kérdéseket.

Az amerikai és szovjet szemlélet különbségeit jól érzékelteti, hogy 1971-ben, a második bjurakani konferencián a földönkívüliekkel való kommunikáció nehézségeivel foglalkozva a szovjet kutatók azt kérdezték, hogy vajon mi garantálja, hogy képesek leszünk megfejteni egy idegen üzenetet, miközben még egyes földi írásokkal sem boldogulunk. Amire Freeman Dyson amerikai fizikus azt mondta, hogy ,a pokolba a filozófiával. Azért jöttem ide, hogy megfigyelésekről és eszközökről halljak." Mint ahogy korábban az amerikai Frank Drake, az 
első SETI-megfigyelési program létrehozója is úgy fogalmazott egy alkalommal, hogy ahelyett, hogy ezen töprengenénk, „gyerünk, és lássunk neki az észlelésnek" (Sheridan, 2011).

Ugyanekkor az első szovjet CETI-kötet szerkesztöje, Samuil A. Kaplan arra hívta fel a figyelmet az 1960-as évek végén, hogy ,a témával kapcsolatos problémák komplex volta abból fakad, hogy elszakíthatatlanul összekapcsolódtak még alapvetőbb problémákkal". A nyelvész Borisz V. Szukotyin (Sukhotin) pedig ugyanebben a kötetben arra, hogy nincs rá garancia, hogy meg tudnánk fejteni egy idegen üzenetet, míg a matematikus Alekszej V. Gladkij (Gladkii) szerint az sem szükségszerü, hogy az idegenek által használt matematika ugyanolyan legyen, mint a miénk stb. (Kaplan, 1971).

Az amerikai és szovjet felfogás közötti különbségek alapján felvethetö, hogy mennyire lenne más a téma megítélése ma, ha nem a SETI-t elsősorban (rádió) csillagászati programként kezelő irányzat határozta volna meg az első évtizedeket, miközben ,a[z amerikai] SETI és a társadalomtudományok közötti kapcsolat jobb esetben is legfeljebb sporadikus volt" (Dick, 2015).

A válasz pedig feltehetően az, hogy egy „elméletibb” megközelítés sem lenne garancia arra, hogy sikerül elörelépnünk. Viszont, hogy a Cocconi-Morrison-cikk zárómondatát parafrazáljuk, ,a siker valószínűségét nehéz megbecsülni; de ha soha nem foglalkozunk az alapkérdésekkel, akkor nulla az esélyünk". Jelenleg ugyanis anélkül keresünk bizonyos típusú jeleket, illetve bizonyos típusú tevékenységek nyomait, hogy sikerült volna tisztáznunk, hogy valójában azok lennének-e egy hipotetikus idegen civilizáció létének az indikátorai. Persze amennyiben létezne egy olyan földönkívüli társadalom, amely nagy energiákat fektet a csillagközi rádióüzenetek küldésébe, akár meg is találhatnánk őket - csak éppen korántsem biztos, hogy éppen ilyesmit kellene keresnünk. És persze az is gondot jelent, hogy a jelenlegi megközelítés meglehetősen valószínűtlenné teszi, hogy a SETI a közeljövőben ugyanolyan elfogadottá váljon, mint az asztrobiológia.

\section{DARWINIZMUS, ELMÉLET, SPEKULÁCIÓ}

A SETI-n belül szokás arra hivatkozni, hogy az UFO-lógia, amit a kívülállók rendszeresen összekevernek a SETI-vel, lejáratja a kutatási területet. Viszont, vegyük észre, hogy a történelmet sem járatják le az összeesküvés-elméletek és az evolúciós elméletet sem a kreácionizmus. A probléma gyökerei valószínűleg legalább részben abban keresendők, hogy az idegen civilizációk kutatására a 20. század második felében a „gyerünk, és csináljuk" mellett három felfogás volt jellemző: az „univerzális darwinizmus”, a „kemény elméleti megközelítés” és „a szabad spekuláció" (Vakoch, 2015). 
Az első értelemszerüen az evolúciós elmélet kiterjesztését jelenti a hipotetikus földönkívüliekre is - azzal a nem elhanyagolható különbséggel, hogy a SETI képviselöi általában természetesnek vették, hogy az evolúció törvényei szükségképpen elvezetnek az élet és az értelem kialakulásához is, miközben az evolúcióbiológusok Theodosius Dobzhanskytól Ernst Mayrig bezárólag rendszerint vitatták ezt, és valószínüleg nem véletlen, hogy a NASA például az 1970-es SETI-konferenciára nem biológusokat, hanem mesterségesintelligencia-szakértőket hívott meg, akik meg voltak róla győződve, hogy az értelmet még mesterségesen is viszonylag egyszerü létrehozni, ezért minden bizonnyal másutt is kifejlődött (Sheridan, 2011).

A második, a ,kemény elméleti megközelítés”, a társadalomtudományok figyelmen kívül hagyásával és implicit módon azt feltételezve próbálta értelmezni a kérdést, hogy a civilizációk fejlődését is ugyanolyan elöíró törvények határozzák-e meg, mint a természettudományokat. Tehát egyfelöl ugyanolyan biztos következtetésre juthatunk, mint adott esetben egy fizikai rendszer tanulmányozásakor; másfelől csupán egyetlen érvényes megoldás képzelhető el. A klasszikus SETI hívei szerint azért is lenne olyan fontos tudnunk, hogy vannak-e nálunk idősebb civilizációk, mert a létük azt bizonyítaná, hogy mi is túlélhetjük az atomfenyegetést, a környezetrombolást stb.

Végezetül, a harmadik megközelítési mód, a „,szabad spekuláció” az, amikor a SETI-vel foglalkozó kutatók megfelelő társalomtudományi ismeretek nélkül, valójában laikusként próbálnak következtetésekre jutni azzal kapcsolatban, hogy milyen lehet egy idegen civilizáció társadalmi berendezkedése; milyen célok megvalósítását tarthatja fontosnak - és így tovább. Eközben hajlamosak ugyanazt a hibát elkövetni, mint Cocconi és Morrison is: előbb kijelentik, hogy valami elképzelhető, majd feltételezik, hogy ha elképzelhető, akkor úgy is van, és különböző állításokat fogalmaznak meg az idegen civilizációkkal kapcsolatban. Egy szélsőséges példa: Carl Sagan amellett érvelt, hogy az idegenek minden bizonnyal „,kozmikus világító bójákat” helyeznek ki a fekete lyukak mellé, hogy figyelmeztessék az arra járókat, tehát ezeknek a jeleit lenne célszerü keresnünk (Sagan, 1973). De ide illik az a mostanában népszerü, „posztbiológiai értelem elképzelés is, mely szerint, ha elképzelhető hatékony kvantumkomputerek építése, és elképzelhető, hogy ezek ,magasabb rendü értelemmel” rendelkeznek (akármit is jelentsen ez), akkor az is elképzelhető, hogy egy fejlettebb civilizáció tagjai önmagukat kvantumkomputerekké alakítva élnek tovább (Davies, 2010).

Röviden: jelenlegi helyzetéből kifolyólag a SETI esetében sokszor olyan mértékben mosódik el a határ a ,tudományosság” és a szórakoztató ötletek felvetése között, mint talán egyetlen más terület esetén sem. És ez nem tesz jót a tudományos megítélésének. 


\section{DE HOL VANNAK A TÁRSADALOMTUDÓSOK?}

Az, hogy a SETI első évtizedeiből egy-két kivételtől (és a szovjet kutatási programoktól) eltekintve látványosan hiányoznak a társadalomtudósok, nem kizárólag arra vezethető vissza, hogy nem vonták be őket. Hanem arra is, hogy - néhány tudománytörténésztől meg kulturális antropológustól eltekintve - a társadalomtudósok sem igazán érdeklődtek a téma iránt. Jelentős részben azért, mert elutasították azokat a feltételezéseket, amelyeken a klasszikus SETI alapult: hogy egy hipotetikus idegen civilizáció szükségképpen eljut a rádió felfedezéséig és a rádiójelek küldéséig; hogy ehhez a matematika univerzálisnak tekintett nyelvét fogják használni, amely a Cocconi-Morrison-irányzat szerint minden bizonnyal megfejthető stb., és ami számos társadalomtudós szerint nagymértékü antropocentrizmus jele. Ugyanekkor a másik oldal képviselői úgy vélték, hogy nem lehet érdemi az a kritika, amely olyan társadalomtudósoktól származik, akik alkalmasint még az alapvető képleteket sem értik (Finney, 1992).

Az utóbbi években azonban megváltozni látszik a helyzet: a NASA például kötetet adott ki a földönkívüli civilizációk kutatása és a régészet lehetséges kapcsolatáról, a Springernek a témában mérvadónak számító sorozatában antropológusok könyvei is megjelennek és így tovább. Röviden: mintha mind a társadalomtudósok, mind a SETI-kutatók nyitnának egymás felé. Ami legalább két kérdést vet fel.

Egyfelöl, hogy ha a jövőben nagyobb lesz a társadalomtudományok szerepe a SETI-n belül, akkor vajon inkább modern csillagászati módszerekkel segített archeológiaként (esetleg antropológiaként) fogunk rá gondolni, vagy egy alapvetően új tudományterület jön létre?

Másfelől: ennek hosszabb távon vajon milyen hatása lehetne a földönkívüli civilizációkkal kapcsolatos kutatások megítélésére? A hagyományos SETI képviselői szeretik azt hangoztatni, hogy egy másik értelmes faj felfedezése ,,mindent megváltoztatna”. Ami valószínüleg nem igaz, hiszen az sem változtatott meg mindent, amikor a 19. század végén, az ún. Mars-őrület idején az vált az általános meggyőződéssé, hogy a Vörös Bolygót nálunk magasabb rendü intelligenciák népesítik be (Traphagan, 2015). És nem is kell, hogy igaz legyen, hacsak nem amellett akarunk érvelni, hogy máskülönben semmi értelme az egész kutatásnak. Viszont a tudományról kialakított képünkbe valószínüleg bőven belefér, hogy egy olyan területnek/témának is szenteljünk némi figyelmet, amelynek a vizsgálata nem változtatna meg ,mindent” - legyen bár szó antropológiáról vagy asztrobiológiáról.

Mármint akkor fér bele, hogy nem úgy csinálja, mint azt a létrejötte utáni első évtizedekben a SETI. 


\section{IRODALOM}

Agar, J. (2012): Science in the Twentieth Century and Beyond. Cambridge: Politiy

Almár I. (1999): A SETI szépsége. Budapest: Vince Kiadó

Basalla, G. (2006): Civilized Life in the Universe: Scientists on Intelligent Extraterrestrials. Oxford: Oxford University Press

Cocconi, G. - Morrison, P. (1959): Searching for Interstellar Communications. Nature, 184, 4690, 844-846.

Crowe, M. J. (1982): The Extraterrestrial Life Debate 1750-1900. The Idea of a Plurality of Worlds From Kant to Lowell. Cambridge: Cambridge University Press

Davies, P. (2010): The Eerie Silence. Are We Alone in the Universe? London: Allen Lane (magyarul: Kísérteties csönd - Egyedül vagyunk a Világegyetemben? Budapest: Akkord Kiadó, 2010)

Dick, S. (1999): The Biological Universe: The Twentieth Century Extraterrestrial Life Debate and the Limits of Science. Cambridge: Cambridge University Press

Dick, S. (2015): The Role of Anthropology in SETI. A Historical View. In: Vakoch, D. (ed.): Archaeology, Anthropology, and Interstellar Communication. (The NASA History Series) Washington

Finney, B. (1992): SETI and the Two Terrestrial Cultures. Acta Astronautica, 26, 3-4., 263-265.

Guthke, K. S. (1990): The Last Frontier. Imagining Other Worlds from the Copernican Revolution to Modern Science Fiction. Ithaca: Cornell University Press

Kaplan, S. A. (ed.) (1971): Extraterrestrial Civilizations - Problems of Interstellar Communication. Jerusalem: IPST (1969, Moszkva: Nauka), https://archive.org/details/nasa_techdoc_19710005278/page/n1

Lamb, D. (2004): The Search for Extraterrestrial Intelligence. A Philosophical Inquiry. London: Routledge

Sagan, C. (1973): The Cosmic Connection. An Extraterrestrial Perspective. New York: Dell Publishing

Sheridan, M. A. (2011): How the Search for Extraterrestrial Intelligence Became Disconnected from New Ideas about Extraterrestrials. ProQuest Dissertations and Theses, Umi Dissertation Publishing

Traphagan, J. (2015): Extraterrestrial Intelligence and Human Imagination: SETI at the Intersection of Science, Religion, and Culture. New York: Springer

Vakoch, D. (2015): The Evolution of Extraterrestrials. The Evolutionary Synthesis and Estimates of the Prevalence of Intelligence Beyond Earth. In: Vakoch, D. (ed.): Archeology, Anthropology, and Interstellar Communication. (The NASA History Series) Washington 